\title{
Et uvanlig funn ved isjialgi
}

Engelsk oversettelse på www.tidsskriftet.no
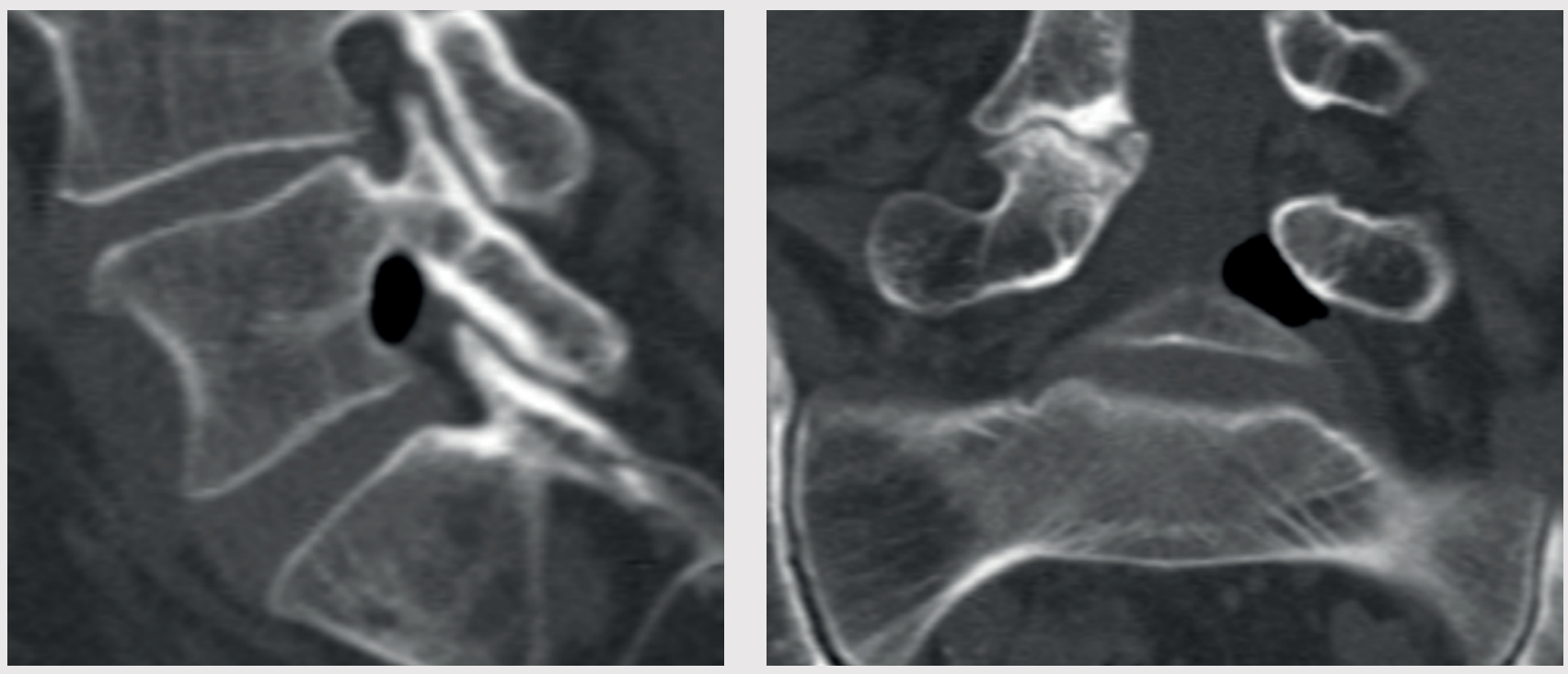

En mann i 60-årene ble innlagt med to dagers sykehistorie med venstresidig isjialgi og pareseutvikling i L5-innervert muskulatur. MR viste en oppfylling i venstre laterale recess i nivå L4/L5 med dorsal dislokasjon av venstre L5-rot. Oppfyllingen hadde uvanlig lavt MR-signal som ga mistanke om forkalkninger eller luft. Supplerende CT viste en velavgrenset luftansamling i samme område (bildene).

Klinisk forverring førte til kirurgisk eksplorasjon av L5-roten. Ventralt for denne så man en luftmengde innkapslet $i$ epiduralt bløtvev, incisjon ble foretatt og luften sluppet fri. Etter dette var L5-roten mykere palpatorisk og hadde fritt forløp. Pasienten opplevde betydelig bedring postoperativt.

Luft i intervertebralskivene, såkalt vakuumfenomen, er et relativt vanlig bildefunn ved degenerative forandringer i lumbalcolumna. I litteraturen rapporteres det om tilfeller med gass i spinalkanalen, intervertebralforamina, i prolapsvev, epiduralt og subaraknoidalt assosiert med vakuum- fenomen (1). Det kan også forekomme sekundært til degenerasjon i fasettledd og ligamenter.

Hos vår pasient forelå bare lettgradig skivebukning uten ruptur $i$ anulus fibrosus og lett fasettleddsartrose $i$ aktuelle nivå. Luften kan representere gassomdanning av et sekvester fra en tidligere prolaps, alternativt pseudocyste assosiert med vakuumfenomen i tilstøtende skiverom. Det er vanskelig å forklare akutt innsettende sykehistorie på bakgrunn av dette, men incisjon og frigjøring av luftansamlingen hos pasienten var likevel terapeutisk.

\section{$\emptyset y s t e i n$ Aamaas}

oystein.aamaas@gmail.com Klinikk for bildediagnostikk

\section{Sozaburo Hara}

Nevrokirurgisk avdeling

St. Olavs hospital

Pasienten har gitt samtykke til at artikkelen blir publisert.
Øystein Aamaas (f. 1977) er under spesialisering i radiologi ved Klinikk for bildediagnostikk. St. Olavs hospital.

Forfatter har fylt ut ICMJE-skjemaet og oppgir ingen interessekonflikter.

Sozaburo Hara (f. 1968) er spesialist i nevrokirurgi og arbeider ved Nevrokirurgisk avdeling, St. Olavs hospital.

Forfatter har fylt ut ICMJE-skjemaet og oppgir ingen interessekonflikter.

Litteratur

1. Choi KC, Kim JS, Lee SH. Surgical experience of gas-containing disk herniation. Neurol Med Chir (Tokyo) 2010; 50: 905-9.

Mottatt 24.4. 2012, første revisjon innsendt 22.6. 2012, godkjent 28.6. 2012. Medisinsk redaktør Merete Kile Holtermann. 